\title{
Determination of metals in sea water of the Baltic Sea in Międzyzdroje
}

\author{
Piotr Daniszewski \\ Department of Invertebrate Zoology and Limnology, Faculty of Biology, University of Szczecin, \\ 13 Wąska Street, 71-415 Szczecin, Poland \\ E-mail address: daniszewski73@gmail.com
}

\begin{abstract}
The present research work deals with the quantification of toxic heavy metals in the water samples collected from sea water in Międzyzdroje. While the annual average concentration of Cadmium was calculated as $0.44 \mathrm{ppm}$ in 2008 of the year and $0.46 \mathrm{ppm}$ in 2009 of the year. The values obtained were found to be below the permissible limit of $2.0 \mathrm{ppm}$ set for inland surface water. While the annual average concentration of Chromium was calculated as $2.67 \mathrm{ppm}$ in 2008 of the year and $2.64 \mathrm{ppm}$ in 2009 of the year. Which was very much above the permissible limit of $0.1 \mathrm{ppm}$ set for inland surface water. The observed annual average concentration of Copper in the water was 0.08 ppm in 2008 of the year and $0.05 \mathrm{ppm}$ in 2009 of the year, which was below the permissible limit of $3.0 \mathrm{ppm}$ set for inland surface water. While the annual average concentration of Mercury was calculated as $0.05 \mathrm{ppm}$ in 2008 of the year and $0.05 \mathrm{ppm}$ in 2009 of the year, which was very much above the maximum limit of $0.01 \mathrm{ppm}$ set for inland surface water. The annual average concentration of Nickel in the water samples was observed to be $2.47 \mathrm{ppm}$ in 2008 of the year and $2.70 \mathrm{ppm}$ in 2009 of the year, which is close to the limit of $3.0 \mathrm{ppm}$ set for inland surface water. The annual average concentration of Lead in the water samples was observed to be $0.06 \mathrm{ppm}$ in 2008 of the year and 0.05 ppm in 2009 of the year, which is above the permissible limit of $0.1 \mathrm{ppm}$ set for inland surface water. The results of the present investigation indicate that the annual average concentration of Zinc in water samples was $3.45 \mathrm{ppm}$ in 2008 of the year and $3.73 \mathrm{ppm}$ in 2009 of the year, which is above the permissible limit of $5.0 \mathrm{ppm}$ set for inland surface water.
\end{abstract}

Keywords: Toxic Heavy Metals; sea water; Baltic Sea

\section{INTRODUCTION}

Urbanization is the cause of many changes which are taking place in the environment, including those found in the catchment. With this in mind, it is an important issue to properly protect water reservoirs and also take action to counter the adverse effects of human activities on the natural environment, including water bodies [1-5,16-21,62-70].

To address the increasing degradation of surface waters in the European Union, the approach to the evaluation and protection of water resources was changed [1-5,16-21,62-70]. This approach was formulated in the European Union Water Framework Directive (2000/60/EC), which calls for the protection of water, as well as an environment-friendly and comprehensive approach to water assessment [1-5,16-21,62-70]. The ecological status of surface waters and groundwater is assessed on the basis of the ecological potential of the biological and physico-chemical and hydromorphological indicators [1-5,16-21,62-70]. 
Heavy metal pollution is an ever increasing problem of our lakes [1-8,52-61]. These toxic heavy metals entering in aquatic environment are adsorbed onto particulate matter, although they can form free metal ions and soluble complexes that are available for uptake by biological organisms [9-17,22-35,52-57,61]. The increase in residue levels of heavy metal content in water, sediments and biota has resulted in decreased productivity and increase in exposure of humans to harmful substances [61].

\section{EXPERIMENTAL}

The Baltic Sea is a mediterranean sea located between Central and Northern Europe, from $53^{\circ} \mathrm{N}$ to $66^{\circ} \mathrm{N}$ latitude and from $10^{\circ} \mathrm{E}$ to $30^{\circ} \mathrm{E}$ longitude. It is bounded by the Scandinavian Peninsula, the mainland of Europe, and the Danish islands [73-77]. It drains into the Kattegat by way of the Øresund, the Great Belt and the Little Belt. The Kattegat continues through Skagerrak into the North Sea and the Atlantic Ocean [73-75]. The Baltic Sea is connected by artificial waterways to the White Sea via the White Sea Canal, and to the North Sea via the Kiel Canal. The Baltic Sea might be considered to be bordered on its northern edge by the Gulf of Bothnia, on its northeastern edge by the Gulf of Finland, and on its eastern edge by the Gulf of Riga. These various gulfs can also be considered part of the Baltic Sea [73-77].

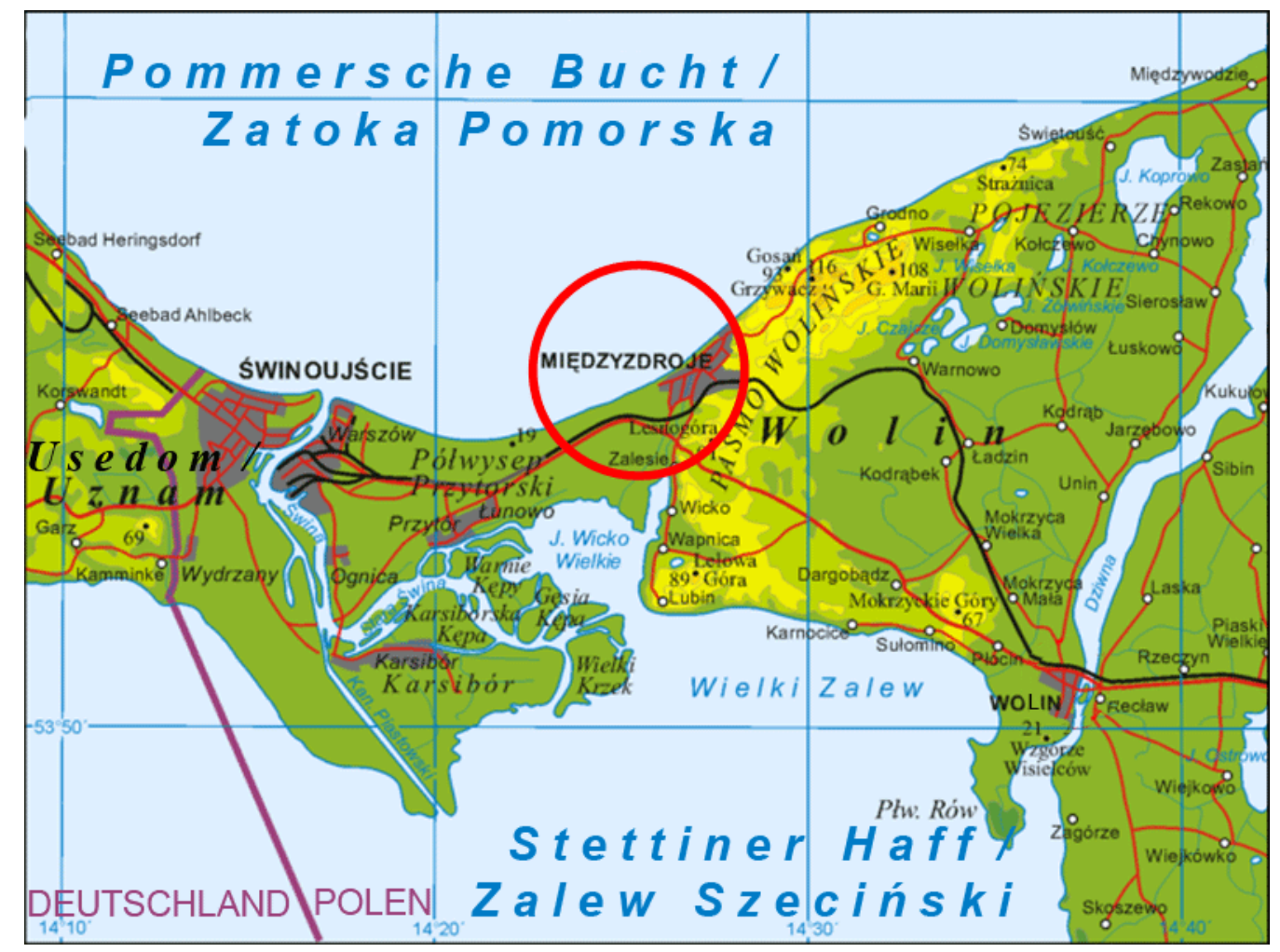

Fig. 1. Map of the Baltic Sea.

Międzyzdroje (German: Misdroy) is a town and a seaside resort in northwestern Poland on the island of Wolin on the Baltic coast. Previously in the Szczecin Voivodeship (19751998), Międzyzdroje has been in Kamień Pomorski County in the West Pomeranian Voivodeship since 1999. Międzyzdroje has a population of 6000 [78-79]. 
The samples were concentrated to tenfold on a water bath and subjected to nitric acid digestion $[14,42]$. About $400 \mathrm{~mL}$ of the sample was transformed into clean glass separating funnel in which $10 \mathrm{~mL}$ of $2 \%$ ammonium pyrrolidine dithiocarbamate, $4 \mathrm{~mL}$ of $0.5 \mathrm{M} \mathrm{HCl}$ and $10 \mathrm{~mL}$ of methyl isobutyl ketone (MIBK) are added $[48,61]$. The solution in separating funnel was shaken vigorously for $2 \mathrm{~min}$ and was left undisturbed for the phases to separate.

The MIBK extract containing the desired metals was then diluted to give final volumes depending on the suspected level of the metals $[13,61]$. The sample solution was then aspirated into air acetylene flame in an atomic absorption spectrophotometer.

The analysis for the majority of the trace metals like Cadmium $(\mathrm{Cd})$, Chromium $(\mathrm{Cr})$, Copper $(\mathrm{Cu})$, Mercury $(\mathrm{Hg})$, Nickel $(\mathrm{Ni})$, Lead $(\mathrm{Pb})$ and Zinc $(\mathrm{Zn})$ was done by Atomic Absorption Spectrophotometer.

\section{RESULTS AND DISCUSSION}

The experimental data on toxic heavy metals in water samples collected along the sea water of the Baltic Sea in Międzyzdroje from the month of April to October 2008 - 2009 is presented in Table 1 and 2.

Table 1. Heavy metals content in water samples collected from of the Baltic Sea in Międzyzdroje (April to October 2008).

\begin{tabular}{|c|c|c|c|c|c|c|c|}
\hline $\begin{array}{c}\text { Heavy } \\
\text { Metals } \\
\text { (ppm) }\end{array}$ & Cd & $\mathbf{C r}$ & $\mathbf{C u}$ & $\mathbf{H g}$ & $\mathbf{N i}$ & $\mathbf{P b}$ & $\mathbf{Z n}$ \\
\hline $\begin{array}{c}\text { Apr. } \\
\mathbf{2 0 0 8}\end{array}$ & 0.42 & 2.81 & 0.09 & 0.04 & 2.46 & 0.06 & 3.53 \\
\hline $\begin{array}{c}\text { May } \\
\mathbf{2 0 0 8}\end{array}$ & 0.48 & 2.29 & 0.08 & 0.04 & 2.37 & 0.05 & 3.55 \\
\hline $\begin{array}{c}\text { June } \\
\mathbf{2 0 0 8}\end{array}$ & 0.46 & 2.63 & 0.08 & 0.05 & 2.51 & 0.05 & 3.41 \\
\hline $\begin{array}{c}\text { July } \\
\mathbf{2 0 0 8}\end{array}$ & 0.44 & 2.68 & 0.09 & 0.05 & 2.43 & 0.03 & 3.46 \\
\hline $\begin{array}{c}\text { Aug. } \\
\mathbf{2 0 0 8}\end{array}$ & 0.52 & 2.82 & 0.08 & 0.04 & 2.39 & 0.04 & 3.34 \\
\hline $\begin{array}{c}\text { Sept. } \\
\mathbf{2 0 0 8}\end{array}$ & 0.39 & 2.75 & 0.07 & 0.04 & 2.56 & 0.04 & 3.56 \\
\hline $\begin{array}{c}\text { Oct. } \\
\mathbf{2 0 0 8}\end{array}$ & 0.41 & 2.72 & 0.09 & 0.05 & 2.61 & 0.06 & 3.31 \\
\hline Average & 0.44 & 2.67 & 0.08 & 0.05 & 2.47 & 0.06 & 3.45 \\
\hline
\end{tabular}


Table 2. Heavy metals content in water samples collected from of the Baltic Sea in Międzyzdroje (April to October 2009).

\begin{tabular}{|c|c|c|c|c|c|c|c|}
\hline $\begin{array}{c}\text { Heavy } \\
\text { Metals } \\
\text { (ppm) }\end{array}$ & Cd & $\mathbf{C r}$ & $\mathbf{C u}$ & $\mathbf{H g}$ & $\mathbf{N i}$ & $\mathbf{P b}$ & $\mathbf{Z n}$ \\
\hline $\begin{array}{c}\text { Apr. } \\
\mathbf{2 0 0 8}\end{array}$ & 0.43 & 2.73 & 0.06 & 0.05 & 2.87 & 0.05 & 3.79 \\
\hline $\begin{array}{c}\text { May } \\
\mathbf{2 0 0 8}\end{array}$ & 0.47 & 2.81 & 0.07 & 0.04 & 2.78 & 0.05 & 3.64 \\
\hline $\begin{array}{c}\text { June } \\
\mathbf{2 0 0 8}\end{array}$ & 0.45 & 2.54 & 0.08 & 0.06 & 2.81 & 0.06 & 3.83 \\
\hline $\begin{array}{c}\text { July } \\
\mathbf{2 0 0 8}\end{array}$ & 0.44 & 2.59 & 0.09 & 0.05 & 2.49 & 0.07 & 3.73 \\
\hline $\begin{array}{c}\text { Aug. } \\
\mathbf{2 0 0 8}\end{array}$ & 0.46 & 2.54 & 0.07 & 0.06 & 2.65 & 0.07 & 3.77 \\
\hline $\begin{array}{c}\text { Sept. } \\
\mathbf{2 0 0 8}\end{array}$ & 0.46 & 2.59 & 0.06 & 0.03 & 2.73 & 0.05 & 3.89 \\
\hline $\begin{array}{c}\text { Oct. } \\
\mathbf{2 0 0 8}\end{array}$ & 0.45 & 2.71 & 0.08 & 0.04 & 2.59 & 0.06 & 3.47 \\
\hline Average & 0.46 & 2.64 & 0.08 & 0.05 & 2.70 & 0.06 & 3.73 \\
\hline
\end{tabular}

In the present investigation, it was observed that the maximum concentration of $\mathrm{Cd}$ was $0.45 \mathrm{ppm}$ and the minimum was $0.19 \mathrm{ppm}$ (Table 1 and 2). While the annual average concentration was calculated as $0.45 \mathrm{ppm}$ in 2008 of the year and $0.29 \mathrm{ppm}$ in 2009 of the year. The values obtained were found to be below the permissible limit of $2.0 \mathrm{ppm}$ set for inland surface water [61]. There are a few recorded instances Cadmium poisoning in human beings following consumption of contaminated fishes [61]. Cadmium it is less toxic to plants than $\mathrm{Cu}$, similar in toxicity to $\mathrm{Pb}$ and $\mathrm{Cr}$ [61]. It is equally toxic to invertebrates and fishes $[40,61]$. In aquatic systems, cadmium is most readily absorbed by organisms directly from the water in its free ionic form $\mathrm{Cd}(\mathrm{II})[5,61]$.

The acute toxicity of cadmium to aquatic organisms is variable, even between closely related species, and is related to the free ionic concentration of the metal [5,61]. Cadmium interacts with the calcium metabolism of animals [5,61]. In fish it causes lack of calcium (hypocalcaemia), probably by inhibiting calcium uptake from the water [5,61]. Effects of long-term exposure can include larval mortality and temporary reduction in growth $[5,61]$.

In the present investigation, it was observed that the maximum concentration of $\mathrm{Cr}$ was $2.98 \mathrm{ppm}$ and the minimum was $2.19 \mathrm{ppm}$ (Table 1 and 2). While the annual average concentration was calculated as $2,78 \mathrm{ppm}$ in 2008 of the year and $2.50 \mathrm{ppm}$ in 2009 of the year. Which was very much above the permissible limit of $0.1 \mathrm{ppm}$ set for inland surface water [61]. For invertebrates and fishes, its toxicity is not much acute [61]. Chromium is generally more toxic at higher temperatures and its compounds are known to cause cancer in humans $[49,61]$. The toxic effect of Chromium on plants indicate that the roots remain small and the leaves narrow, exhibit reddish brown discoloration with small necrotic blotches [30]. Symptoms of Chromium phytotoxicity include inhibition of seed germination or of early seedling development, reduction of root growth, leaf chlorosis and depressed biomass $[50,61]$. 
From the results it appears that the $\mathrm{Cu}$ content in the lake water was minimum of 0.04 ppm and maximum of $0.08 \mathrm{ppm}$ (Table 1 and 2). The observed annual average concentration of Copper in the water was $0.06 \mathrm{ppm}$ in 2008 of the year and $0.05 \mathrm{ppm}$ in 2009 of the year, which was below the permissible limit of $3.0 \mathrm{ppm}$ set for inland surface water [61]. It is important here to note that Copper is highly toxic to most fishes, invertebrates and aquatic plants than any other heavy metal except mercury [61]. It reduces growth and rate of reproduction in plants and animals [61]. The chronic level of $\mathrm{Cu}$ is $0.02-0.2 \mathrm{ppm}[61,67]$. Aquatic plants absorb three times more Copper than plants on dry lands [61]. Excessive Copper content can cause damage to roots, by attacking the cell membrane and destroying the normal membrane structure, inhibited root growth and formation of numerous short, brownish secondary roots $[61,67]$. Copper is highly toxic in aquatic environments and has effects in fish, invertebrates, and amphibians, with all three groups equally sensitive to chronic toxicity $[29,61]$. Copper also causes reduced sperm and egg production in many species of fish [53$56,61,66]$.

In the present investigation, it was observed that the maximum concentration of $\mathrm{Hg}$ was $0.06 \mathrm{ppm}$ and the minimum was $0.03 \mathrm{ppm}$ (Table 1 and 2). While the annual average concentration was calculated as $0.04 \mathrm{ppm}$ in 2008 of the year and $0.04 \mathrm{ppm}$ in 2009 of the year, which was very much above the maximum limit of $0.01 \mathrm{ppm}$ set for inland surface water [61]. Mercury is generated naturally in the environment from the degassing of the earth's crust from volcanic emissions [61].

The organic form is readily absorbed in the gastrointestinal tract (90-100 \%), lesser but still significant amounts of inorganic mercury are absorbed in the gastrointestinal tract (7-15 \%) [61]. Previous study have reported that Mercury in dissolved form enter the fish through the gills $[15,61]$. Further studies have indicated that inorganic Mercury get adsorbed to the suspended particulate matter and settles down $[33,61]$. Further gets methylated and ultimately enter the food chain, resulting in bioaccumulation [61].

The monthly concentration of $\mathrm{Ni}$ in the lake water samples was found to be in the range of $1.78 \mathrm{ppm}-2.81 \mathrm{ppm}$ (Table 1 and 2). The annual average concentration of Nickel in the water samples was observed to be $2.19 \mathrm{ppm}$ in 2008 of the year and $2.42 \mathrm{ppm}$ in 2009 of the year, which is close to the limit of $3.0 \mathrm{ppm}$ set for inland surface water [61]. Short-term exposure to Nickel on human being is not known to cause any health problems, but long-term exposure can cause decreased body weight, heart, liver damage and skin irritation $[61,67]$.

In the present investigation, it was observed that the maximum concentration of $\mathrm{Pb}$ was $0.07 \mathrm{ppm}$ and the minimum was $0.04 \mathrm{ppm}$ (Table 1 and 2). The annual average concentration of $\mathrm{Pb}$ in the water samples was observed to be $0.06 \mathrm{ppm}$ in 2008 of the year and $0.05 \mathrm{ppm}$ in 2009 of the year, which is above the permissible limit of $0.1 \mathrm{ppm}$ set for inland surface water [61]. Acute toxicity generally appears in aquatic plants at concentration of 0.1-5.0 ppm $[61,67]$. In plants, it initially results in enhanced growth, but from a concentration of $5 \mathrm{ppm}$ onwards, this is counteracted by severe growth retardation, discoloration and morphological abnormalities [61]. There is an adverse influence on photosynthesis, respiration and other metabolic processes [61]. Acute toxicity of Lead in invertebrates is reported at concentration of 0.1-10 ppm [61,67]. Higher levels pose eventual threat to fisheries resources [61]. A number of studies have investigated effects of prolonged Lead exposure on freshwater fish [61]. These studies report a wide range of effects induced by chronic exposure to elevated Lead concentrations, oocyte growth, including effects on pituitary function, gonadosomatic index $[47,61]$.

In the present study, the monthly concentration of Zinc was in the range of $2.54 \mathrm{ppm}$ to $3.75 \mathrm{ppm}$ (Table 1 and 2). The results of the present investigation indicate that the annual 
average concentration of $Z n$ in water samples was $3.25 \mathrm{ppm}$ in 2008 of the year and $2.95 \mathrm{ppm}$ in 2009 of the year, which is above the permissible limit of $5.0 \mathrm{ppm}$ set for inland surface water [61]. Zn may result in ne crosis, chlorosis and inhibited growth of plants [61,67]. Previous studies have reported toxic effect of Zinc on some aquatic organisms such as fish $[3,61]$. Although there is low toxicity effect of $\mathrm{Zn}$ in man, however, the prolonged consumption of large doses has been reported to show some health complications such as fatigue, dizziness and neutropenia $[28,61]$.

\section{CONCLUSION}

1. While the annual average concentration of Cadmium was calculated as $0.44 \mathrm{ppm}$ in 2008 of the year and $0.46 \mathrm{ppm}$ in 2009 of the year.

2. While the annual average concentration of Chromium was calculated as $2.67 \mathrm{ppm}$ in 2008 of the year and 2.64 ppm in 2009 of the year.

3. The observed annual average concentration of Copper in the water was $0.08 \mathrm{ppm}$ in 2008 of the year and 0.05 ppm in 2009 of the year.

4. While the annual average concentration of Mercury was calculated as $0.05 \mathrm{ppm}$ in 2008 of the year and $0.05 \mathrm{ppm}$ in 2009 of the year.

5. The annual average concentration of Nickel in the water samples was observed to be $2.47 \mathrm{ppm}$ in 2008 of the year and $2.70 \mathrm{ppm}$ in 2009 of the year.

6. The annual average concentration of Lead in the water samples was observed to be $0.06 \mathrm{ppm}$ in 2008 of the year and $0.05 \mathrm{ppm}$ in 2009 of the year.

7. The results of the present investigation indicate that the annual average concentration of Zinc in water samples was $3.45 \mathrm{ppm}$ in 2008 of the year and $3.73 \mathrm{ppm}$ in 2009 of the year.

\section{References}

[1] Adams W. J., Kimerle R. A., Barnett J. W. Jr., Environ. Sci. Technol. 26(10) (1992) 1864-1875.

[2] Aghor A., Chemicals make Thane creek the worst polluted waterbody, Daily DNA, August 4, 2007. Mumbai, India, 2007

[3] Alabaster J. S., Lloyds R., Water quality criteria for freshwater fish. Second edition, Butterworths publication, London 1982, pp. 361.

[4] Ali N. A., Ater M., Sunahara G. L., Robidoux P. Y., Ecotoxicology and Environmental Safety 57(3) (2004) 363-374.

[5] AMAP. Assessment report: Arctic pollution issues. Arctic Monitoring and Assessment Programme, Oslo 1998.

[6] Baršytė Lovejoy D., Acta Zoologica Lituanica. Hydrobiologia 9(2) (1999) 12-20.

[7] Baldwin D. H., Sandahl J. F., Labenia J. S., Scholz N. L. Environmental Toxicology and Chemistry 22(10) (2003) 2266-2274.

[8] Bradl H., Heavy Metals in the Environment: Origin, Interaction and Remediation, Elsevier/Academic Press, London 2005. 
[9] Cai L., Liu G., Rensing C., Wang G., BMC Microbiology 9(4) (2009), doi:10.1186/1471 2180-9-4.

[10] Carlos-Tarres-Guzman M., Moreno-Sanchez R., FEMS Microbiol. Rev. 25(3) (2001) 335-347.

[11] Cervantes C., Campos-Garcia J., Debars S., Gutierrez-Corona F., Loza-Tavera H., Chatterjee J., Chatterjee C., Environ. Pollut. 109(1) (2000) 69-74.

[13] Chen M., Ma L. Q., Soil Science Society of American Journal 65(2) (2001) 491-499.

[14] Clesceri L. S., Standard methods for the examination of Water and waste water. In Arnold, E., Greenbergy, Eaton, A.D. (Eds.): Collection and Preservation of Samples And Metals, pp.1-27, pp.1-35, pp.3-1, pp.3-21, APHA, AWWA, WEF, Washington DC 1998.

[15] Dallinger R., Prosi F., Segner H., Back H., Oecologia. 73(1) (1987) 91-98.

[16] Daniszewski P., Wiadomości Melioracyjne i Łąkarskie 4 (2008) 187-188.

[17] Daniszewski P., Ekologia i Technika 5 (2008) 211-214.

[18] Daniszewski P., Inżynier budownictwa 11 (2009) 81-82.

[19] Daniszewski P., Gaz, Woda i Technika Sanitarna 4 (2009) 34-36.

[20] Daniszewski P., International Letters of Chemistry, Physics and Astronomy 5 (2012) $72-79$

[21] Daniszewski P. International Letters of Chemistry, Physics and Astronomy 5 (2012) $80-87$

[22] Das H. K., Mitra A. K., Sengupta P. K., Hossain A., Islam F., Rabbani, G. H., Environment International. 30(3) (2004) 383-387.

[23] Dube B. K., Tewari K., Chatterjee J., Chaterejee C., Chemosphere. 53(9) (2003) 1147-1153.

[24] Ember L., Environ. Sci. Tech. 9(13) (1975) 116-121.

[25] Ezeonyejiaku C. D., Obiakor, M. O., Ezenwelu C. O., Online Journal of Animal and Feed Research 1(4) (2011) 130-134.

[26] Gbaruko B. C., Ana G. R. E. E., Nwachukwu J. K., African Journal of Biotechnology $7(25)(2008)$ 4737-4742.

[27] Health Organisation, International Programme on Chemical Safety (IPCS), Geneva 1992, Switzerland.

[28] Hess R., Schmid B., J. Paediatr. Haematol. Oncol. 24 (2002) 582-584.

[29] Horne M. T., Dunson W. A., Archives of Environmental Contamination and Toxicology 29(4) (1995) 500-505.

[30] Jha S. K., Chavan S. B., Pandit G. G., Negi B. S., Sadasivan S., Environmental Monitoring and Assessment. 76(2) (2002) 249-262.

[31] Kabata-Pendias A., Pendias H., Trace Elements in Soils and Plants. 2nd ed. CRC Press, Boca Raton 1992, pp. 365. 
[32] Kazi T. G., Arain M. B., Baig J. A., The Science of the Total Environment. 407(3) (2009) 1019-1026.

[33] Kehrig H.A., Malm O., Moreira I., Sci. Tot. Environ. 213(1-3) (1998) 263-271.

[34] Khunyakari R. P., Vrushali T., Sharma R. N., Tare V., Journal of Environmental Biology 22 (2) (2001) 141-144.

[35] Lokhande R. S., Kelkar N., Indian Journal of Environmental Protection 19(9) (1999) 664-668.

[36] Lokhande R. S., Singare P. U., Pimple D. S., Resources and Environment. 1(1) (2011) 13-19.

[37] Lokhande R. S., Singare P. U., Pimple D. S., World Environment 1(1) (2011) 6-13.

[38] Maher W., Batley G. E., Lawrence I., Freshwater Biol. 41(2) (1999) 361-372.

[39] Menounou N., Presley B. J., Arch. Environ. Contam. Toxicol. 45(1) (2003) 11-29.

[40] Moore J. W., Ramamoorthy S., Heavy Metals in Natural Waters: Applied Monitoring and Impact Assessment, Springer-Verlag, New York 1984, pp. 28-246.

[41] Neff J. M., Environmental Toxicology and Chemistry 16(5) (1997) 917-927.

[42] Paar A., Microwave Sample Preparation System - Instruction Handbook, Anton Paar GmbH, Austria 1998, pp. 128.

[43] Patil D., A lot's fishy about our creek and lake fish. Daily Times of India. March 22, Mumbai 2009, India. Obtained through the Internet:

[44] Pyatt A. J., Pyatt F. B., Pentreath V. W., Invertebr Neurosci. 4(3) (2002) 135-140.

[45] Rai U. N., Tripathi R. D., Kumar N., Glaucocystis nostochinearum ltzigsohn. Chromosphere. 25 (1992) 721-732.

[46] Rozsa K. S., Salanki J., Cell Mol. Neurobiol. 14(6) (1994) 735-754.

[47] Ruby S. M., Hull R., Anderson P., Arch Environ Contam Toxicol. 38(1) (2000) 46-51.

[48] Sachdev S. L., West P. W., Environmental Science \& Technology 4(9) (1970) 749-751.

[49] Saxena D. K., Srivastava K., Singh S., Current Science 94(7) (2008) 901-904.

[50] Sharma D. C., Pant R. C., Journal of Environmental Science and Health. Part A 29(5) (1994) 941-948.

[51] Sharma R. K., Agrawal M., Marshall F. M., Effects of waste water irrigation on heavy metal accumulation in soil and plants, Paper presented at the National Seminar, Bangalore University, Bangalore 2004, India.

[52] Singare P. U., Interdisciplinary Environmental Review 12(4) (2011) 298-312.

[53] Singare P. U., Lokhande R. S., Bhanage S. V., International Journal of Global Environmental Issues. 11(1) (2011) 79-90.

[54] Singare P. U., Lokhande R. S., Naik K. U., Interdisciplinary Environmental Review $12(3)(2011) 215-230$.

[55] Singare P. U., Lokhande R. S., Naik K. U., Interdisciplinary Environmental Review 11(1) (2010) 90-107. 
[56] Singare P. U., Mishra R. M., Trivedi M. P., Advances in Analytical Chemistry 2(3) (2012) 14-24.

[57] Singare P. U., Mishra R. M., Trivedi M. P., Frontiers in Science. 2(3) (2012) 28-36.

[58] Singare P. U., Thane lakes high on metal content: Study, Daily Times of India, August 10, 2011. Mumbai, India.

[59] Singare P. U., Trivedi M. P., Mishra R. M., American Journal of Chemistry 2(3) (2012) 171-180.

[60] Singare P. U., Trivedi M. P., Mishra R. M., Science and Technology 2(4) (2012) 87-97.

[61] Singare P.U., Talpade M.S., Dagli D.S., Bhawe V.G. International Letters of Chemistry, Physics and Astronomy 8(2) (2013) 94-104

[62] Spooner D. R., Maher W., Otway N., Arch. Environ. Contam. Toxicol. 45(1) (2013) 92-101.

[63] Sunderman F. W., Arch Ind. 20(1) (1959) 36-41.

[64] Swamy Y. V., Roy Chaudhury G., Das S. N., Sengupta S., Muduli R., Current Science 91(10) (2006) 1409-1412.

[65] Szucs A., Salanki J., Rozsa K. S., Cell Mol. Neurobiol. 14(6) (1994) 769-780.

[66] Taub Frieda B., Fish 430 lectures (Biological Impacts of Pollutants on Aquatic Organisms), University of Washington College of Ocean and Fishery Sciences, Seattle 2004, WA.

[67] Tiwana N. S., Jerath N., Singh G., Ravleen (Eds.), Heavy metal pollution in Punja Rivers, in Newsletter Environmental Information System (ENVIS), Punjab State Council for Science and Technology, India, 3(1) (2005) 3.

[68] Vymazal J., Algae and Element Cycling in Wetlands. Lewis Pub., Boca Raton 1995, pp. 689.

[69] WHO. Cadmium - environmental aspects. Environmental Health Criteria 135. World Health Organisation, International Programme on Chemical Safety (IPCS), Geneva 1992, Switzerland.

[70] Wright D. A., Welbourn P., Environmental Toxicology, Cambridge University Press, Cambridge 2002, U.K.

[71] Zawadzka-Kahlau E., Tendencje rozwojowe polskich brzegów Bałtyku południowego,

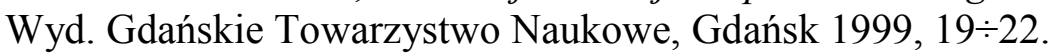

[72] Sato N., Corrosion - The Journal of Science and Engineering 45(5) (1989) 354 368 .

[73] Heino, R. et al. (34 authors) Past and current climate change. In: The BACC Author Team, Assessment of Climate Change for the Baltic Sea Basin. Springer Verlag, Berlin, Heidelberg. (2008), 473 pp.

[74] Fagerli, H., S. Valiyaveetil. Atmospheric Supply of Nitrogen, Lead, Cadmium, Mercury and Dioxines/Furanes to the Baltic Sea in 2006. Available online: http://www.helcom.fi/stc/files/environment/EMEP_2006/Chapter3_nitrogen.pdf [Viewed15 January 2009]. 
[75] Fleming-Lehtinen, V., M. Laamanen, H. Kuosa, H. Haahti, R. Olsonen, Long-term development of inorganic nutrients and chlorophyll a in the open Northern Baltic Sea. Ambio (2008), 37:86-92.

[76] Hongisto, M. \& S. Joffre, Boreal Environment Research 10 (2005) 1-17.

[77] Olli, K., A. Clarke, Å. Danielsson, J. Aigars, D. J. Conley, T. Tamminen, Journal of Marine Systems 73 (2008) 284-299.

[78] Port Świnoujście. Urząd Morski w Szczecinie. 2008

[79] Port w Świnoujściu - nabrzeża. Zarząd Morskich Portów Szczecin i Świnoujście SA. 2009. 